\title{
ПУБЛІЧНО-ПРАВОВИЙ МЕХАНІЗМ ЗАБЕЗПЕЧЕННЯ НАЦІОНАЛЬНОЇ БЕЗПЕКИ ДЕРЖАВИ
}

\author{
КОБКО Свген Васильович - кандидат юридичних наук, доцент, доцент \\ кафедри публічного управління та адміністрування Національна академія \\ внутрішніх справ \\ КОБКО Василь Андрійович - кандидат історичних наук, доцент, професор \\ кафедри профілактики пожеж та безпеки життедіяльності населення Інститут \\ державного управління та наукових досліджень 3 цивільного захисту \\ САМІЛО Андрій Вікторович - кандидат юридичних наук, доцент, т.в.о \\ завідувача кафедри права та менеджменту у сфері цивільного захисту, Львівський \\ державний університет безпеки життсдіяльності \\ УДК 344.3+341.233.11+341.32:341.48/.49 \\ DOI 10.32782/NP.2021.4.5
}

В статье проведен анализ публично пра-
вового механизма обеспечения начиональ-
ной безопасности государства через опре-
деление его элементов и характеристику каж-
дого из них. Указано, что прерогативой для
Украинъ, которая находится в состоянии
войнъ и сочиальнъхх възовов, обусловленньх
внергетическим и пандемическим кризисом,
является обеспечение членов сочиума - лич-
ности, отдельнъх групп населения, общества
в челом, а также защить прав человека и
гражданина.

Позиционирована доктрина американской и польской школь права по пониманию сущности национальной безопасности, как важного Фактора обеспечения национальных интересов и как одна из основньих сфер функциионирования государства, обеспечивающая возможность въюшвания, а также развития и свободъ реализации прав человека.

Проанализировав международнъие и начиональнье стандарть в сбере начиональной безопасности, исследовав научнъле позиици представителей украинской и зарубежной доктринъ, считаем необходимым въцелить четьире уровня публично правового механизма обеспечения национальной безопасности государства. К первому уровню мв отнесем нормативный блок средств, ко второму - правоприменительную деятельность; третий уровень - институциональнъй, а четвертъий, считаем, что должен быть представлен идеологическими гарантиями формирования и обеспечения национальной безопасности. Рассмотрим их поподробнее.

Мотивировано, что нормативнылй уровень механизма национальной безопасности включает в себя всю правовую политику государства в этой сфере. Конституиия Украинъ определяет ключевъге положения, указьвая, что человек, его жизнь и здоровъе, честь и достоинство, неприкосновенность и безопасность признаются в Украине висшей соииальной ценностью. Развитие этих положений осуществляется в отраслевом законодательстве. В статье обобщено, что нормативные положения имеют пространную структуру норм права, их согласованность, системность.

Авторь обосновали структуру органов публичной власти, наделеннве полномочиями обеспечения национальной безопасности: законодательные органы; высшие и центральнъле органъ исполнительной власти; Президента Украинъг; судебньие органъ; правоохранительнье и контрольно-надзорнъле органы и органы местного самоуправления.

Ключевъие слова: начиональная безопасность, информационная безопасность, экологическая безопасность, органь публичной власти, механизм начиональной безопасности. 


\section{Адміністративне право}

\section{Постановка проблеми}

Національна безпека нині є не тільки основою функціонування держави, але й потребою громадянського суспільства та ключовим елементом забезпечення прав людини. Прерогативою для України, яка перебуває в стані війни та соціальних викликів, зумовлених енергетичною та пандемічною кризою, є убезпечення членів соціуму - особистості, окремих груп населення, суспільства в цілому, а також захисту прав людини і громадянина. Охорона безпеки людини виступає основним завданням демократичної держави, показником належності до цивілізованих народів. Добробут суспільства, права, свободи та законні інтереси, у першу чергу, громадян детерміновано критерієм державної політики та $\epsilon$ стратегічним напрямком діяльності органів публічної влади.

Конституційна основа функціонування України вказує, що людина, її права і свободи $є$ найвищою цінністю відповідно до ст. 3 Основного закону. Така правова природа відносин між державою і суспільством обумовлює зобов'язання першої щодо визнання, дотримання і захисту прав і свобод людини і громадянина. Безпека людини виступає домінуючим компонентом у єдиній системі безпеки держави.

Важливо розуміти, що елементами національної безпеки не є лише оборонні засоби та методи щодо дотримання територіально цілісності держави. Досліджуване поняття має набагато ширшу сутність. Варто погодитися 3 провідними науковцями, що доводять потребу системного убезпечення п'яти сфер, що «безпосередньо впливають на національну та міжнародну безпеку: демократизація, економізація та інформатизація, культурна стандартизація і ціннісна універсалізація. Ці процеси неминуче наштовхуються на національну ідентичність як на перешкоду своєму природному розвитку. Втрата національної ідентичності веде, як показує світова практика, до втрати не тільки національних ціннісних орієнтирів, але і значної частини національного суверенітету держави, і становить пряму загрозу для національної безпеки. Це, у свою чергу, означає відмову від власних національних інтересів, нездатність цих держав до самостійної як внутрішньої, так і зовніш- ньої політики. I навпаки, чітке самовизначення, тверда опора на національну ідентичність, відкривають можливість проводити свій власний внутрішньо- і зовнішньополітичний курс у міжнародній політиці, заснований на глибоко усвідомлених і чітко сформульованих національних інтересах»[1, с.71].

Як вказують міжнародні фахівці (Alam, M.M., Fawzi, A.M., Islam, M.M.), спалах COVID-19 у всіх країнах світу сильно впливає на питання національної безпеки, зокрема на нетрадиційні питання безпеки, такі як правоохоронні органи, охорона здоров'я, харчування, управління ланцюгом поставок, промисловість тощо [2]. Отож питання національної безпеки активізується також у контексті загроз громадському здоров'ю, що зумовлена пандемією COVID-19.

Вказане зумовлює потребу доктринального аналізу методологічного осмислення модернізаційних засобів та методів правового регулювання та праксіологічного убезпечення безпеки людини, суспільства і держави, джерел та передумов іï здійснення. Для належного функціонування сфери національної безпеки необхідним 6 комплексний механізм організаційних та інституційних засобів, тому вагомо на науковому рівні проаналізувати цю концептуальну основу.

Метою наукової статті $€$ аналіз публічно правового механізму забезпечення національної безпеки держави через визначення його елементів та характеристику кожного з них.

\section{Виклад основних положень}

Проблеми захисту прав та свобод людини і громадянина, територіальної цілісності та протидії різним видам безпекових загроз аналізувалися такими представниками національної та зарубіжної школи права, як О. Дзьобань, Н. Бортник, I. Жаровська, В. Аіпкан А, Н. Нижник, I. Оніщенко, М. Сунгуровський, О. Мельник, Г. Іванец,Ю. Битяк, І. Яковюк, С. Г. Серьогіна, Ю. П. Битяк, Alam M., Fawzi A., Islam M.,Nevitt M. та інші. Проте проблема потребує додаткового аналізу у зв'язку з появою нових загроз та викликів, а також тому, що наразі відсутні комплексні дослідження механізму забезпечення національної безпеки держави. 


\section{Виклад основних положень}

Національну безпеку вчені первинно називають безпекою нації й під цим поняттям розуміють захищеність життєво важливих інтересів особи, суспільства і держави в різних сферах життєдіяльності від внутрішніх і зовнішніх загроз, що забезпечує сталий поступальний розвиток країни [3]. Так, американська концепція національної безпеки грунтується на теорії «національних інтересів», і саме звідси бере початок відповідна модель співвідношення, у якій національна безпека розглядається як частина національних інтересів. Така модель нині набула широкого визнання. Вперше іiі запропонував американець У. Аиппман. Дослідниками цієї проблеми були також Б. Броуді. М. Гальперін,Г. Кан, Г. Кіссінджер, Г. Аасвел, Г. Моргентау $[4$, c. 53].

Польська наукова доктрина розуміє національну безпеку як одну з основних сфер функціонування держави, що забезпечує можливість виживання, а також розвитку та свободи реалізації національних інтересів у конкретному безпечному середовищі, приймаючи виклики, використовуючи можливості, зменшуючи ризики та протидіючи різним видам загроз [5, с.17]

Слід звернути увагу, що пріоритети сфери національної безпеки змінюються залежно від територіальних, культурних, правових та інших соціальних особливостей держави та політичної ситуації. Зокрема, для України зараз це, безумовно, оборона територіальної цілісності, а от проаналізована нами Стратегія національної безпеки Сінгапуру акцент робить на подоланні проблем тероризму [6].

Хоча при цьому потрібно збалансовано і виважено акцентувати увагу на всіх загрозах. Політика в цій сфері повинна передбачати прогностичне методологіювання. Національна безпека в останній час, - як вказує I.М. Жаровська, - у зв'язку з викликами глобалізації, кризовими явищами сучасного суспільства та трансформацією інформаційного простору, отримала нову актуалізацію [7, с.56]. Тому нині вагомо розуміти комплексний характер проблеми національної безпеки.

Акцентуємо увагу, що питання екологічної безпеки є не менш вагомими, ніж інші, і заходяться в цілісному концепті проблемати- ки. У звіті Пентагону США за 2019 р. про національну безпеку мотивовано, що «кліматичні небезпеки, такі як екстремальна погода, високі температури, посухи, повені, лісові пожежі, шторми, підвищення рівня моря, деградація грунту та закислення океанів, посилюються, загрожуючи інфраструктурі, здоров'ю, водній та продовольчій безпеці» та спричинятимуть загострення національній безпеці у світі [8]. Отож природні ресурси при умовах недостатності можуть слугувати підставою військових дій та інших політичних заворушень.

Під механізмом у юридичній науці класично розуміють «сукупність усіх правових засобів, організованих послідовно, за допомогою яких забезпечується результативний спеціально-юридичний вплив на суспільні відносини» [9, с. 48].

Проаналізувавши міжнародні та національні стандарти у сфері національної безпеки, дослідивши наукові позиції представників української та зарубіжної доктрини, вважаємо за необхідне виокремити чотири рівні публічно правового механізму забезпечення національної безпеки держави. До першого рівня ми віднесемо нормативний блок засобів, до другого - правозастосовну дільність; третій рівень - інституційний, а четвертий, вважаємо, має бути репрезентований ідеологічними гарантіями формування та забезпечення національної безпеки. Розглянемо їх детальніше.

Нормативний рівень механізму національної безпеки комплексно включає всю правову політику держави у цій сфері. Фахівці у сфері адміністративного права доречно розуміють правову політику як «особливе політико-правове явище у сфері суспільних відносин, що представляє інтегративну, науково обгрунтовану, що поєднує тактико-стратегічні засади, здійснювану на правовій основі за допомогою права діяльність державних і недержавних інститутів суспільства, спрямована на створення та вдосконалення механізму правового впливу з метою розвитку громадянського суспільства, правової держави, забезпечення прав і свобод» ${ }^{1}[10$, с.62].

\footnotetext{
${ }^{1}$ Бортник Н. П., Парпан У. М., Малець М. Р. Міграційна політика та міграційно-правова політика: порівняльний аналіз. Европейські перспективи. 2019.
} № 4. C. $60-66$ 


\section{Адміністративне право}

Конституція України визначає ключові положення, вказуючи, що людина, ії життя і здоров’я, честь і гідність, недоторканність і безпека визнаються в Україні найвищою соціальною цінністю. Розвиток цих положень здійснюється в галузевому законодавстві.

Комплексна правова політика у сфері національної безпеки прийнята нещодавно та введена в дію Указом Президента України №392/2020 «Про рішення Ради національної безпеки і оборони України від 14 вересня 2020 року «Про Стратегію національної безпеки України» [11]. П. 6 визначеного акту визначає напрямами політики у сфері національної безпеки, серед яких відновлення миру, територіальної цілісності та державного суверенітету на тимчасово окупованих територіях у Донецькій і Луганській областях України на основі міжнародного права; здійснення міжнародно-правових, політикодипломатичних, безпекових, гуманітарних та економічних заходів, спрямованих на припинення Російською Федерацією незаконної окупації Автономної Республіки Крим та міста Севастополь; використання всіх наявних механізмів ООН, Ради Европи, ОБСЕ, інших міжнародних організацій для консолідації міжнародної підтримки України; повна імплементація Угоди про асоціацію між Україною; розвиток особливого партнерства 3 Організацією Північноатлантичного договору з метою набуття повноправного членства України в НАТО; посилення спроможностей Збройних сил України, інших органів сектору безпеки і оборони; розвиток людського капіталу України; захист особи, суспільства та держави від правопорушень; забезпечення екологічної безпеки; посилення спроможностей національної системи кібербезпеки та ряд інших. Позитивно оцінюємо наявність нормативного акту спеціального спрямування - Закону України «Про національну безпеку України», що прийнятий Верховною Радою 21 червня 2018 року[12].

Система законодавства представлена в цій сфері достатньо широко, тому перерахуємо тільки основні акти, які посилюють правове регулювання у сфері національної безпеки, зокрема Закони України «Про оборону України» від 06.12.1991 № 1932-XII, «Про Раду національної безпеки і оборони України» від
05.03.1998 № 183/98-ВР, «Про правовий режим воєнного стану» від 12.05.2015 № 389VIII; Кодекс Цивільного захисту України від 02.10.2012 № 5403-VI; «Про Службу безпеки України» від 25.03.1992 № 2229-XII; «Про боротьбу з тероризмом» України від 20.03.2003 № 638-IV, «Про інформацію» від 02.10.1992 № 2657-XII, «Про Бюро економічної безпеки України» від 28.01.2021 № 1150-IX; Указ Президента України від 29.12.2016 року «Про Доктрину інформаційної безпеки України», «Про рішення Ради національної безпеки і оборони України від 14 травня 2021 року «Про Стратегію кібербезпеки України»» від 26 серпня 2021 року, Розпорядження Кабінету Міністрів України від 20.10.2021 № 1363-р «Про схвалення Стратегії екологічної безпеки та адаптації до зміни клімату на період до 2030 року» та багато інших.

Загалом можемо констатувати, що нормативні положення мають розлогу структуру норм права, їх узгодженість, системність. Позитивно оцінюємо систематичне оновлення нормативно правової бази відповідно до вимог соціальної реальності, появі додаткових загроз та тенденцій євроінтеграційного та євроатлантичного курсу нашої держави.

Правореалізащійний рівень забезпечення національної безпеки. Норми права без фактора правореалізаційної діяльності не мають дієвого механізму, тому й позбавлені цінності, оскільки тоді залишаються декларативними нормами. Як вказує Я. Шморгун, «статичне утримання механізму реалізації права включає конкретні правові зобов'язання, юридичні факти їх реалізації, власне правореалізаційну діяльність суб'єктів права, правовідносини, у яких втілюється відповідне право» [13, c.247].

На жаль, в Україні виникає цілий комплекс проблем у сфері реалізації норм права. Гіпотетичними та найбільш вірогідними джерелами загроз національній безпеці $є$ політичні загрози від окупації значної частини території держави, існування самопроголошених республік, військовий конфлікт 3 державою агресором, посилення сепаратизму, нестабільність біля північних кордонів держави, міграційна криза в Білорусії та проблеми пандемічного характеру. У межах цієї статті ми не можемо навіть частково охопити 
широту цієї проблематики, тому обмежимось лише останніми ситуаціями та подіями.

У першу чергу проблеми мають фінансовий характер. Станом на жовтень цього року борги по заробітній платі військовослужбовцям сягають 3 млрд грн, потреби армії недофінансовані більше ніж на 7 млрд[14] Значні непередбачувані витрати 3 бюджету на боротьбу із загрозами громадського здоров'я, зокрема, за офіційними даними, тільки за перші п’ять місяців 2021 року з державного бюджету на боротьбу 3 коронавірусом було спрямовано 19,5 млрд грн [15]. Поряд з цим можна констатувати не завжди розумно мотивовані рішення в цій сфері. Зокрема, у 2021 році більше половини суми фонду по боротьбі 3 COVID-19 , а саме 35 мільярдів направили на міністерство інфраструктури для реалізації великого будівництва та ремонту доріг, а Мiністерство охорони здоров'я отримало тільки 8,3 мільярди [16].

Не сприяють належній правореалізаційній практиці і випадки помилок, що здійснюються органами публічної влади найвищого рівня. 15 жовтня 2021 року Секретар Ради нацбезпеки та оборони визнав, що було помилково зачислено 108 осіб деяких людей до переліку кримінальних авторитетів, щодо яких ввели санкції [17].

Слід взяти до увагу думки професора О. Колби щодо такого. До особливостей реалізації нормативно-правових актів, що стосуються змісту національної безпеки України, можна віднести у сьогоденні свавільне порушення деякими суб'єктами кримінально-процесуальної діяльності положень ст.216 КПК України, відповідно до яких встановлена підслідність досудового розслідування кримінальних правопорушень, включаючи й слідчі органи безпеки (ч.2 ст. 216). Сутність цієї проблематики полягає у тому, що замість того, щоб предметно займатись запобіжною та іншими видами оперативно-службової діяльності, які входять у коло їх функціональних обов'язків, деякі керівники сил безпеки (п.17 ч.1 ст.1 та ч.2 ст.17 Закону України «Про національну безпеку»), отримавши відповідну інформацію, що є підставою для внесення в Сдиний реєстр досудових розслідувань (ЕРДР) (ст.214 КПК), замість того, щоб переадресувати іiі по підслідності, продовжують здійснювати досу- дове розслідування та складають обвинувальний акт, «прикрашуючи» таким чином свої прорахунки, а подекуди бездіяльність по тих напрямах, які є безпосереднім предметом їх діяльності [18, с.106-107].

Закордонні дослідники акцентують на потребі урівноваження компетенції органів влади та заходів забезпечення національної безпеки. Так, у своєму підручнику «Закон про національну безпеку та Конституція» (2020) експерти ООН і професори навчальних закладів СШІА [19] розглядали зважений підхід при застосуванні конституційних основ розвитку політики національної безпеки та здійснення широкого кола повноважень у сфері національної безпеки.

Інституиійний рівень включає функціонування органів публічної влади, їх повноваження та завдання у сфері національної безпеки.

$3 У$ «Про національну безпеку України» виокремлює сфери, де уповноваженими 6 різні органами. Так, демократичний цивільний контроль відповідно до Розділу III здійснюеться Президентом України; Верховною Радою України; Радою національної безпеки і оборони України; Кабінетом Міністрів України, органами виконавчої влади та органами місцевого самоврядування; судового контролю; громадського нагляду. Розділ IV Закону вказує, що до складу сектору безпеки і оборони входить цілий ряд органів виконавчої влади за спрямуванням.

Отож, перелік суб'єктів є доволі широким, вказане зумовлено глобальністю розглядуваного поняття. Тому в межах цієї статті сконцентруємося на структурі цих органів. На нашу думку, загалом їх можна виокремити в наступну структуру: законодавчі органи; вищі та центральні органи виконавчої влади; Президента України; судові органи; правоохоронні та контрольно наглядові органи та органи місцевого самоврядування.

Загалом первинне місце у цій структурі відіграє Верховна Рада України та Президент. Відповідно до ст. 13 ЗУ «Про національну безпеку України» керівництво у сферах національної безпеки і оборони відповідно до Конституції України здійснює Президент України, який: забезпечує державну незалежність та національну безпеку; є Верхо- 


\section{Адміністративне право}

вним Головнокомандувачем Збройних Сил України; очолює Раду національної безпеки і оборони України; видає укази і розпорядження з питань національної безпеки і оборони; вносить до Верховної Ради України подання про призначення Міністра оборони України; вносить до Верховної Ради України подання про призначення на посаду та звільнення 3 посади Голови Служби безпеки України; призначає на посади та звільняє з посад вище командування Збройних Сил України; здійснює загальне керівництво розвідувальними органами України; вносить до Верховної Ради України подання про оголошення стану війни та у разі збройної агресії проти України ухвалює рішення про застосування Збройних сил України та інших утворених відповідно до законів України військових формувань; ухвалює відповідно до закону рішення про загальну або часткову мобілізацію та введення воєнного стану в Україні та здійснює інші повноваження.

Проте, дослідники визначають ряд проблем. К. Парубець вказує, що «за умов неповної правової регламентації повноважень існує різна практика реалізації функцій контролю Президента України. У сфері національної безпеки і оборони такий контроль здійснюється через Раду національної безпеки і оборони України та ії спеціальні робочі органи, через спеціально визначений військовий орган та через діяльність спеціального уповноваженого. Водночас чинне законодавство містить досить численні прогалини та неузгодження щодо правового статусу та обсягу повноважень зазначених органів та осіб. Слід також зазначити, що вони (органи й особи) фактично позбавлені власних повноважень у цій сфері» [20, с.65].

Ідеологічні гарантї національної безпеки репрезентовані на четвертому рівні. Громадянське суспільство $є$ також вагомим суб’єктом національної безпеки. Думка громадськості, моніторинг та експертиза від іiі імені, функціонування громадських рад, петиційна форма звернення до органів публічної влади, робота громадських та волонтерських організацій - це тільки основний перелік прояву активності у сфері національної безпеки.
У цьому контексті позитивно оцінюємо зміни, що відбулися у свідомості та ментальності української нації. 3 часу реальної загрози національної безпеки та територіальної цілісності у 2014 році значно підвищилася активність громадськості та зріс рівень патріотизму. Для прикладу зазначимо останню статистичну аналітику. Загальнонаціональне опитування проведене Фондом «Демократичні ініціативи» імені Ілька Кучеріва з 29 липня по 4 серпня 2021, продемонструвало, що 78\% українців вважають своєю рідною мовою українську, а 18\% - російську[21]. Вказане демонструє ріст патріотизму громадськості та відстоювання власної ідентичності.

\section{Висновок}

Національну безпеку позиціоновано як вагомий чинник забезпечення національних інтересів та як одну з основних сфер функціонування держави, що забезпечує можливість виживання, а також розвитку та свободи реалізації прав людини.

До механізму забезпечення національної безпеки віднесено чотири рівні засобів: нормативний блок засобів (нині нормативні положення мають розлогу структуру норм права, передбачають узгодженість, системність та систематично оновлюються); правореалізаційний рівень (забезпечують дієвий механізм використання, виконання дотримання та застосування норм; констатовано наявність недоліків фінансового, організаційного та правосуб'єктного характеру); інституційний рівень включає функціонування органів публічної влади, їх повноваження та завдання у сфері національної безпеки (виокремлено наступну структуру органів: законодавчі органи; вищі та центральні органи виконавчої влади; Президента України; судові органи; правоохоронні та контрольно наглядові органи та органи місцевого самоврядування); ідеологічні гарантії національної безпеки (комплекс морально-патріотичних та націоналістичних засобів, щодо підвищення патріотизму членів громадянського суспільства).

\section{Мiтература}

1. Подолян Ю. О. Сутність категорії «права та свободи людини» як ціннісного еле- 
менту в побудові системи забезпечення національної безпеки України Dictum factum. 2021. № 1. С. 68-75 C. 71

2. Alam M.M., Fawzi A.M., Islam M.M. et al. Impacts of COVID-19 pandemic on national security issues: Indonesia as a case study. Secur Jornal. 2021. URL: https://doi.org/10.1057/ s41284-021-00314-1

3. Ліпкан В.А. Національна безпека України : навч. посіб. Київ : КНТ, 2009.С. 193-198

4. Глобальна та національна безпека / авт. кол. В. І. Абрамов, Г. П. Ситник, В. Ф. Смолянюк. Київ: НАДУ при Президентові України, 2016. 784 с

5. Słownik terminów $\mathrm{z}$ zakresu bezpieczeństwa narodowego. Pod kierownictwem d-ra hab. inż. Bogdana Zdrodowskiego. Warszawa: Wydawnictwo Akademii Obrony Narodowej. Wydział Strategiczno-Obronny, 2008. 182 s. URL: https://docplayer.pl/1120197Akademia-obrony-narodowej-wydzialstrategicznoobronny-slownik-terminow-zzakresu-bezpieczenstwa-narodowego.html

6. Singapore's Cybersecurity Strategy. Security Agency of Singapore. 2018. URL:https:// www.csa.gov.sg/ news/publications/singaporecybersecurity-strategy/ / media/0ecd8f67 laf 2447890ec046409a62bc7.ashx.

7. Жаровська I. Національна та інформаційна безпека (актуалізація в сучасних умовах) Вісник Начіонального університету «Һьвівсъка політехніка». Серія : Юридичні науки. 2020. T. 7, № 3. С. 56-61. С. 56

8. Nevitt M. On Environmental Law, Climate Change, \& National Security Law Harv. Envtl. L. Rev. 2020. V. 44 P.321

9. Алексеев C. С. Механизм правового регулирования в социалистическом государстве. Москва: Юрид. ^-ра, 1966. 186 с.

10. Бортник Н. П., Парпан У. М., Малець М. Р. Міграційна політика та міграційно-правова політика: порівняльний аналіз. Европейсъкі перспективи. 2019. № 4. С. 60-66.

11. Про рішення Ради національної безпеки і оборони України від 14 вересня 2020 року «Про Стратегію національної безпеки України»: указ Президента України №392/2020 URL: https://www.president.gov.ua/ documents/3922020-35037
12. Про національну безпеку України: закон України від 21.06.2018 № 2469-VIII Відомості Верховної Ради. 2018, № 31, ст.241.

13. Шморгун Я. О. Реалізація права громадянина на участь в управлінні справами держави Молодий вчений. 2021. № 1(2). С. 246248.

14. Борги ЗСУ цього року сягають 3 млрд гривень. 15 жовня 2021. URL: https://b.ua/ society/2021/10/15/496304_borgi_zsu_tsogo_ roku_syagayut_3_mlrd.html

15. У Мінфіні підрахували витрати на боротьбу з коронавірусом 3 початку року URL: https://www.slovoidilo.ua/2021/06/17/novyna/ finansy/minfini-pidraxuvaly-vytraty-borotbukoronavirusom-pochatku-roku

16. Куди пішли гроші з фонду боротьби COVID-19 і за що долати епідемію у майбутньому? URL: https://www.radiosvoboda. org/a/30809286.html

17. РНБО помилково зарахувала до «ворів в законі» 108 людей URL: https://www.bbc. com/ukrainian/news-58901124

18. Колб О. Г., Дучимінська А. М. Про деякі особливості реалізації на практиці та забезпечення національної безпеки України Вісник Пенітенціарної асочіацій Украйни. 2020.№ 2. C. 103-109

19. Corn G. S., Gurule J., Kahn J.D. National Security Law and the Constitution. Gary Wolters Kluwer Law \& Business, 2020 p.1032 p.

20. Парубець К. А. Повноваження президента України у сфері забезпечення національної безпеки Dictum factum. 2021. № 1.C. 60-67.

21. Фонд «Демократичні ініціативи» імені Ілька Кучеріва» URL: https:/dif. org.ua/article/den-ukrainskoi-pisemnosti-tamovi-2021-chi-stae-derzhavnoi-movi-bilshe-upublichnomu-prostori_?fbclid = IwAR2fNz4uTYIavd8aZbHHiJSCp̈U-rv6VZVz-Md7O0fOOIznoi9Kfav9RC6k

\section{PUBLIC-LEGAL MECHANISM FOR ENSURING THE NATIONAL SECURITY OF THE STATE}

The article analyzes the public-law mechanism for ensuring the national security of the state through the definition of its elements and the characteristics of each of them. It is stated 


\section{Адміністративне право}

\section{АНОТАЦІЯ}

У статті проведено аналіз публічно правового механізму гарантування національноі безпеки держави через визначення його елементів та характеристику кожного з них. Вказано, шуо прерогативою для України, яка перебуває в стані війни та соиіальних викликів, зумовлених енергетичною та пандемічною кризою, є убезпечення членів сочіуму - особистості, окремих груп населення, суспільства в изілому, а також захисту прав людини $i$ громадянина.

Позичіоновано доктрину американсъкої та польської шкіл права щодо розуміння сутності національної безпеки як вагомого чинника забезпечення національних інтересів та як одну з основних сбер функціонування держави, що забезпечує можливість виживання, а також розвитку та свободи реалізачиї прав людини.

Проаналізувавши міжнародні та начіональні стандарти у сфері начіональної безпе$\kappa$, дослідивши наукові позищї представників украӥнсъкої та зарубіжної доктрини, вважаємо за необхідне виокремити чотири рівні публічно-правового механізму забезпечення начіональної безпеки держави. До першого рівня ми віднесемо нормативний блок засобів, до другого - правозастосовну діяльність; третій рівень - інституційний, а четвертий, вважаємо, має бути репрезентований ідеологічними гарантіями бормування та забезпечення наиіональної безпеки. Розглянемо їх детальніше.

Мотивовано, що нормативний рівень механізму національної безпеки комплексно включає всю правову політику держави у иій сфері. Конституиія України визначає ключові положення, вказуючи, що людина, ї̈ життя $i$ здоров'я, честь $i$ гідність, недоторканність $i$ безпека визнаються в Украӥні найвищою соціальною изнністю. Розвиток изи положень здійснюється в галузевому законодавстві. У статті узагальнено, що нормативні положення мають розлогу структуру норм права, їх узгодженість, системність.

Автори обгрунтували структуру органів публічної влади, що наділені повноваженнями забезпечення начіональної безпеки: законодавчі органи; вищі та центральні органи виконавчої влади; Президента Украӥни; судові органи; правоохоронні та контрольно наглядові органи та органи місцевого самоврядування.

Ключові слова: начіональна безпека, iнбормаційна безпека, екологічна безпека, органи публічної влади, механізм начіональноі безпеки. that the prerogative for Ukraine, which is at war and social challenges caused by the energy and pandemic crisis is to protect members of society individuals, groups, society as a whole, as well as the protection of human and civil rights.

The doctrine of the American and Polish schools of law on understanding the essence of national security as an important factor in ensuring national interests and as one of the main areas of state functioning, ensuring the possibility of survival, development and freedom of human rights.

Having analyzed international and national standards in the field of national security, examining the scientific positions of representatives of Ukrainian and foreign doctrine, we consider it necessary to distinguish four levels of public legal mechanism for national security. To the first level we will carry the normative block of means, to the second - law enforcement activity; the third level is institutional, and the fourth we believe should be represented by ideological guarantees of the formation and maintenance of national security. Consider them in more detail.

It is motivated that the normative level of the national security mechanism comprehensively includes all legal policy of the state in this sphere. The Constitution of Ukraine defines key provisions, stating that a person, his life and health, honor and dignity, inviolability and security are recognized in Ukraine as the highest social value. The development of these provisions is carried out in the sectoral legislation. The article summarizes that the regulations have a broad structure of rules of law, their consistency, system.

The authors substantiated the structure of public authorities endowed with the powers to ensure national security: legislative bodies; higher and central executive bodies; President of Ukraine; judicial authorities; law enforcement and control supervisory bodies and local selfgovernment bodies.

Key words: national security, information security, ecological security, public authorities, national security mechanism. 